\title{
Electrochemical Biosensor-Based Devices for Continuous Phenols Monitoring in Environmental Matrices
}

\author{
Renato S. Freire ${ }^{a}$, Nelson Durán ${ }^{a, b}$ and Lauro T. Kubota ${ }^{*, a}$ \\ ${ }^{a}$ Instituto de Química, Universidade Estadual de Campinas, CP 6154, 13083-970 Campinas - SP, Brazil \\ ${ }^{b}$ Núcleo de Ciências Ambientais - Universidade de Mogi das Cruzes, Mogi das Cruzes - SP, Brazil
}

\begin{abstract}
Desenvolveu-se um método de análise em fluxo para a determinação contínua de compostos fenólicos em matrizes ambientais, usando-se uma membrana de diálise para amostragem e biossensores a base de lacase e tirosinase para a detecção destes compostos. A resposta dos biossensores frente a diferentes compostos fenólicos foi investigada. O biossensor a base de lacase mostrou uma alta sensibilidade para guaiacol e cloroguaiacol, enquanto que o biossensor de tirosinase foi mais sensível para fenol e clorofenol. Ambos os biossensores apresentaram respostas seletivas para concentrações destes compostos em níveis micromolares. Limites de detecção de 1,1 x $10^{-7} \mathrm{~mol}$ $\mathrm{L}^{-1}$ para guaiacol e de $1,9 \times 10^{-7} \mathrm{~mol} \mathrm{~L}^{-1}$ para cloroguaiacol foram obtidos usando-se o biossensor a base de lacase. Empregando-se o biossensor a base de tirosinase obteve-se limites de detecção de 1,5 x $10^{-7} \mathrm{~mol} \mathrm{~L}^{-1}$ para fenol e de $9,0 \times 10^{-8} \mathrm{~mol} \mathrm{~L}^{-1}$ para clorofenol. O método de análise em fluxo proposto apresentou um faixa linear de trabalho entre $1,0 \mu \mathrm{mol} \mathrm{L}^{-1} \mathrm{e} 100,0 \mu \mathrm{mol} \mathrm{L}^{-1}$, nas condições operacionais otimizadas dos biossensores (biossensor a base de lacase: $\mathrm{pH}$ 5,0 e potencial de trabalho $0 \mathrm{mV} v s \mathrm{Ag} / \mathrm{AgCl}$; biossensor a base de tirosinase: $\mathrm{pH}$ 5,0 e potencial de trabalho $50 \mathrm{mV} v s$ $\mathrm{Ag} / \mathrm{AgCl}$ ). Uma amostra real de efluente papeleiro foi analisada pelo sistema proposto e pelo método colorimétrico de referência e os resultados discutidos.
\end{abstract}

\begin{abstract}
A flow system method for continuous determination of phenolic compounds in environmental matrices was employed using a dialysis membrane sampler and laccase- and tyrosinase-based biosensors as detector. The biosensors response to different phenolic compounds was investigated. The laccase-based biosensor showed high sensitivity to guaiacol and chloroguaiacol, while the tyrosinase-based biosensor was more sensitive to phenol and chlorophenol. Both of the biosensors presented highly selective measurements of micromolar concentration of these compounds. Detection limits around $1.1 \times 10^{-7} \mathrm{~mol} \mathrm{~L}^{-1}$ for guaiacol and $1.9 \times 10^{-7} \mathrm{~mol} \mathrm{~L}^{-1}$ for chloroguaiacol could be estimated for the laccase-based biosensor. Using the tyrosinase-based biosensor detection limits of $1.5 \times 10^{-7} \mathrm{~mol} \mathrm{~L}^{-1}$ for phenol and $9.0 \times 10^{-8} \mathrm{~mol} \mathrm{~L}^{-1}$ for chlorophenol were observed. The proposed flow method presented a linear response range between $1.0 \mu \mathrm{mol} \mathrm{L}^{-1}$ and $100.0 \mu \mathrm{mol} \mathrm{L}^{-1}$, in the optimized operational conditions (laccase-based biosensor: $\mathrm{pH} 5.0$ and $0 \mathrm{mV} v s \mathrm{Ag} / \mathrm{AgCl}$ as working potential; tyrosinase-based biosensor: $\mathrm{pH} 5.5$ and $50 \mathrm{mV} v s \mathrm{Ag} / \mathrm{AgCl}$ as working potential). Real paper mill effluent sample was analyzed by this system and by the reference colorimetric method and the results were discussed.
\end{abstract}

Keywords: amperometric biosensors, continuous monitoring, environmental samples, phenolic compounds

\section{Introduction}

The release of phenol and its chlorinated derivatives into the environmental is of great concern. A considerable number of organic pollutants, widely distributed throughout the environment, have a phenolic structure.

* e-mail: kubota@iqm.unicamp.br
Thus, there is a continuously increasing demand for selective and sensitive detection of phenols since these toxic compounds are widely used in the manufacture of various industrial products ${ }^{1,2}$ and they are known to be widespread as components of industrial waste. ${ }^{3,4}$ Phenolic compounds are a class of polluting chemicals, easily absorbed by animals and humans through the skin and mucous membranes. ${ }^{5}$ Their toxicity is directly towards a 
great variety of organs and tissues, primarily lungs, liver, kidneys and genito-urinary system. ${ }^{5,6}$ Many phenols, especially chlorophenols, are known for their persistency in the environment and propensity for bioconcentration and biomagnification. ${ }^{7}$

Several procedures have been developed for the determination of phenolic compounds, such as chromotographic techniques, fluorimetric and spectrophotometric methods.${ }^{68}$ However, these techniques do not easily allow continuous monitoring in real samples. They are expensive, time-consuming, need skilled operators, and sometimes require preconcentration and extraction steps that increase the risk of samples loss. ${ }^{9,10}$

Biosensors represent promising tools to supplement already existing techniques, due to their intrinsic characteristics such as selectivity, low cost, potential for miniaturization/automation, and for the construction of simple flow devices for fast continuous monitoring. ${ }^{11}$ Laccase and tyrosinase are copper containing enzymes that catalyse the reduction of molecular oxygen by different electron donors, e.g. phenolic compounds. In these reactions oxygen is reduced directly to water without the intermediate formation of hydrogen peroxide; on the other hand, phenols are converted into quinones and/or radical species. ${ }^{12}$ These liberated species can be electrochemically reduced to allow convenient low-potential detection of the phenolic analytes. Reagentless devices based on the immobilization of laccase or tyrosinase onto various carbon or platinum transducers have been developed. ${ }^{4}{ }^{13}$ Such devices rely on monitoring the liberation of the enzymatic products or the consumption of the oxygen. These two enzymes display different substrate selectivity and mechanisms, and thus the use of laccase and tyrosinase-based biosensors on the analysis of environmental samples allows the detection of different phenolic compounds. ${ }^{12,14}$

In this paper different electrochemical biosensors were evaluated for on-line monitoring of phenolic compounds. The sensitivity and selectivity capabilities of laccase and tyrosinase-based biosensors were coupled to the advantages of an integrated flow injection/analyte collector system. Operational conditions and performance of this device are reported for monitoring guaiacol, chloroguaiacol, phenol and chlorophenol.

\section{Experimental}

\section{Reagents}

All solutions were prepared with deionized water. Laccase (from Coriolus hirsutus, E.C. 1.10.3.2, $416 \mathrm{U} \mathrm{mg}^{-1}$ ) was received from SynectiQ Corp. (Dover, New Jersey,
USA). Tyrosinase (2000 $\mathrm{U} \mathrm{mg}^{-1}$, EC 1.14.18.1) was purchased from ICN (USA). Bovine serum albumin was received from Sigma, 1-cyclohexyl-3-(2-morpholinoethyl) carbodiimide metho- $p$-toluenosulfonate, glutaraldehyde $(50 \%(\mathrm{~m} / \mathrm{v})$, water solution, reagent grade), $p$-chlorophenol, phenol and guaiacol were purchased from Aldrich, and chloroguaiacol, from Research Chemical. Tests were carried out using a phosphate buffer solution ( $\mathrm{pH} 5.0,10 \mathrm{mmol} \mathrm{L}^{-1}$ ) and the Kraft $\mathrm{E}_{1}$ (alkaline extraction) effluent was obtained from a paper mill industry in the Campinas city region (São Paulo State, Brazil) which processes Eucalyptus grandis wood. The effluent was stored at $4{ }^{\circ} \mathrm{C}$ in glass flasks and used without previous filtration or any other treatment.

\section{Apparatus and procedure}

Experiments were performed with the Amperometric Biosensor Detector (Universal Sensors, Inc.; New Orleans/ USA) model $3001 \mathrm{ABD}$ amperometric analyzer, connected to a X-Y-t recorder model RB 101 from ECB (São Paulo/ Brazil). Amperometric experiments were carried out applying a potential step (of $0 \mathrm{mV}$ and $50 \mathrm{mV} v s \mathrm{Ag} / \mathrm{AgCl}$, for laccase and tyrosinase-based biosensors, respectively) and recording the current transient. All experiments were carried out at room temperature.

\section{Electrode pre-treatment and enzyme immobilization}

The glassy carbon electrodes were pre-treated at a potential of $+2.00 \mathrm{~V} v s \mathrm{Ag} / \mathrm{AgCl}$ for 5 minutes in $0.1 \mathrm{~mol} \mathrm{~L}^{-1}$ phosphate buffer ( $\mathrm{pH}$ 7.2), using a platinum wire as the counter electrode. After this process, the electrodes were allowed to react for $2 \mathrm{~h}$ with a solution of 1-cyclohexyl-3(2-morpholinoethyl)carbodiimide metho- $p$-toluenosulfonate in $0.05 \mathrm{~mol} \mathrm{~L}^{-1}$ acetate buffer at $\mathrm{pH} 4.8$ (with continuous stirring). ${ }^{17}$ Then, the electrodes were dipped, during 30 minutes, into a solution of glutaraldehyde (10 $\left.\mathrm{mg} \mathrm{mL}^{-1}\right)$, bovine serum albumin $\left(6 \mathrm{mg} \mathrm{mL}^{-1}\right)$ and enzyme ( $300 \mathrm{U} \mathrm{mL}^{-1}$ laccase or $900 \mathrm{U} \mathrm{mL}^{-1}$ tyrosinase).

\section{Flow injection system}

For flow injection (FI) measurements the biosensor was inserted into a confined wall jet amperometric flow cell as shown in Figure 1 (i and iii). The holder for the membrane, shown in Figure 1 (ii), is consisted of two acrylic blocks with identical machined grooves having the dimension of $100 \times 3 \times 0.25 \mathrm{~mm}$, forming channels with a nominal volume of $150 \mu \mathrm{L}$, with $5 \mu \mathrm{L}$ of dead volume. A cellulose membrane (MWCO: 12000, Sigma) previously immersed 


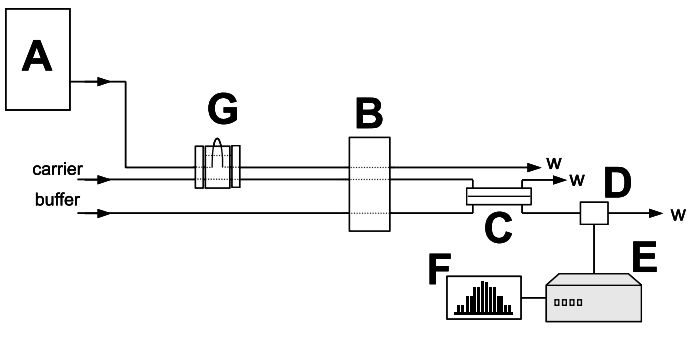

(i)

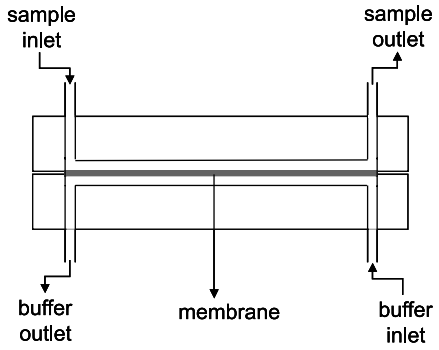

(ii)

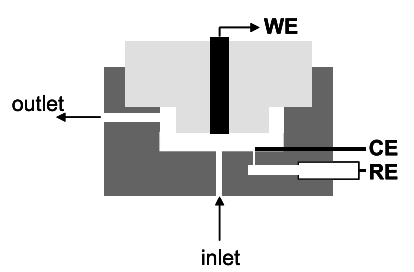

(iii)

Figure 1. Schematic diagram of the analytical system. Flow injection assembly (i): sample (A); pump (B); permeation cell (C); electrochemical detector (D); potentiostat (E); recorder (F); injector (G) and waste (w). Permeation cell (ii): the cellulose membrane is placed between two blocks made in acrylic, the two channels (donor and acceptor) that are formed have a nominal volume of $150 \mu \mathrm{L}$. Electrochemical cell (iii): laccasebased or tyrosinase-based working electrode (WE); counter electrode (CE), and Ag/AgCl reference electrode (RE).

in deionized water for 10 minutes was placed between the two blocks, which were tightly clamped with six bolts. The flow rates employed, for both internal and external solution, were $1.6 \mathrm{~mL} \mathrm{~min}{ }^{-1}$, previously optimized.

\section{Colorimetric analysis}

The total phenols concentration was determinated by Folin-Ciocalteu's reaction according to APHA. ${ }^{15,16}$ In this analysis, $1 \mathrm{~mL}$ of sample was mixed with $250 \mu \mathrm{L}$ of $0.1 \mathrm{~mol} \mathrm{~L}^{-1}$ tartarate-carbonate buffer at $\mathrm{pH} 12$ and $25 \mu \mathrm{L}$ of Folin-Ciacalteu's reagent. ${ }^{15}$ The mixture was kept in reaction during 30 minutes at $20{ }^{\circ} \mathrm{C}$, then the absorbance of the solution was monitored at $700 \mathrm{~nm}$, using a Hitachi spectrophotometer Model U-2000.

\section{Results and Discussion}

Detection of phenols using the enzyme electrodes shows several advantages over both soluble enzyme assay methods and direct electrochemical oxidation. ${ }^{4,17}$ The signal amplification through cycling of the quinone product has been shown to increase the sensitivity of the enzyme electrode assay response. ${ }^{18,19}$ Compared with the electrochemical oxidation of phenols, the biosensors tend to be more stable, selective, and better suited to potential environmental applications. These favorable characteristics result from the reduction of quinones species that avoids its polymerization over the electrode surface. In addition, the biosensors require a lower potential (around $0.0 \mathrm{~V}$ ) than direct oxidation (around $+1.0 \mathrm{~V}$ ), becoming less expose to interferences. ${ }^{17,18}$

An enzyme electrode configuration relies on the biochemical recognition and the electrochemical transduction. The effectiveness of the biosensor is determined by the manufacture procedure, mainly in the bioactive component immobilization procedure. ${ }^{13}$ In order to obtain a highly sensitive sensing surface, a substrate molecule needs to be able to interact without steric restrictions. One approach to this is the covalent protein immobilization, ideally at a site that does not affect the active site of the enzyme. In this study, the immobilization of laccase or tyrosinase over the glassy carbon electrode surface was promoted using carbodiimide and glutaraldehyde simultaneously. As described previously, ${ }^{13}$ this immobilization procedure has produced laccase-based biosensors with better stability and sensitivity, and these characteristics are desired for detector in flow systems.

The behavior of these biosensors in a flow system was investigated in terms of working potential, $\mathrm{pH}$, stability and sensitivity to different phenolic compounds.

\section{Effect of working potential}

The variation of biosensors response with the applied potential was investigated using $200 \mu \mathrm{L}$ injections of 
$50 \mu \mathrm{mol} \mathrm{L}{ }^{-1}$ guaiacol and $50 \mu \mathrm{mol} \mathrm{L} \mathrm{L}^{-1}$ phenol for laccase and tyrosinase-based biosensor, respectively. The flow rate employed was $1.60 \mathrm{~mL} \mathrm{~min}^{-1}$ and a $0.1 \mathrm{~mol} \mathrm{~L}^{-1}$ phosphate buffer solution at $\mathrm{pH} 5.0$, used as the carrier. As shown in Figure 2 (a), laccase-based biosensor redutive detection of the liberated enzymatic products starts at $250 \mathrm{mV} v s \mathrm{Ag} /$ $\mathrm{AgCl}$, with a maximum response around $0 \mathrm{mV}$, keeping this plateau until $-300 \mathrm{mV}$. A very similar behavior was observed for the tyrosinase-based biosensor, which starts its response at $300 \mathrm{mV}$, and signal rises sharply up to $150 \mathrm{mV}$ and decreases above $0 \mathrm{mV}$.

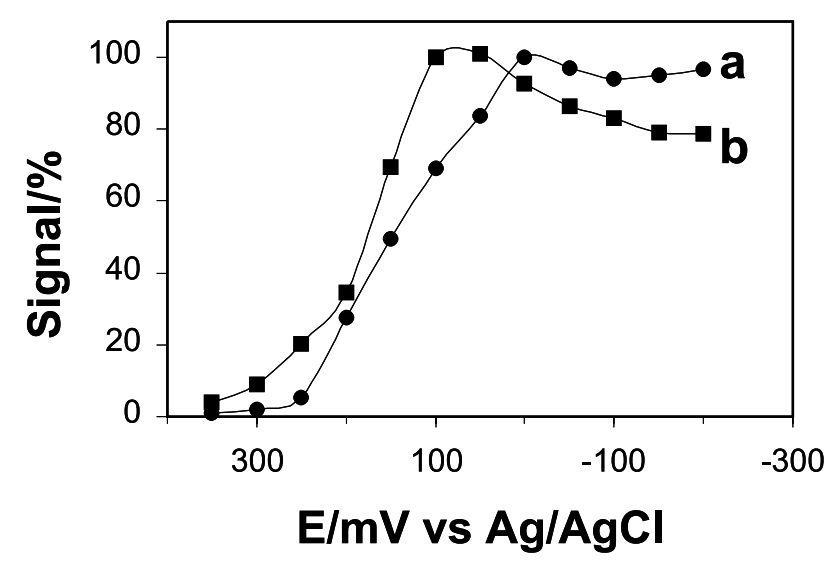

Figure 2. Hydrodynamic voltammogram for laccase-based biosensor (a) and tyrosinase-based biosensor (b) inserted in a flow injection system (flow-rate: $1.6 \mathrm{~mL} \mathrm{~min}$ ). Injected volume: $220 \mu \mathrm{L}$ of $50 \mu \mathrm{mol} \mathrm{L}-1$ guaiacol (for laccase biosensor) and $220 \mu \mathrm{L}$ of $50 \mu \mathrm{mol} \mathrm{L}^{-1}$ phenol (for tyrosinase biosensor); carrier solution: phosphate buffer (10 mmol L-1, pH 5.0); and internal solution: phosphate buffer $\left(10 \mathrm{mmol} \mathrm{L}^{-1}, \mathrm{pH} 5.0\right.$ and 5.5; for laccase- and tyrosinase-based biosensors, respectively).

Thus, further experiments were carried out at $0 \mathrm{mV}$ for laccase-based biosensor and at $50 \mathrm{mV}$ for tyrosinase-based biosensor. This working potential range is very favorable, since few contaminants expected to be present in environmental samples are reduced at low potentials (between 0.1 and $0.0 \mathrm{~V}$ vs $\mathrm{Ag} / \mathrm{AgCl}$ ). In addition, in these potentials low noise level and low background currents were observed.

\section{Effect of $p H$}

Figure 3 (A) presents the influence of $\mathrm{pH}$ upon the laccase (a) and tyrosinase-based (b) biosensors response, both of the biosensors showed a good sensitivity over a broad range (between 4.0 and 7.0). It is observed that the tyrosinase-based biosensor has a broader range than the laccase-based, remaining at $50 \%$ of its signal in $\mathrm{pH} 7.5$ against only $7 \%$ for the laccase biosensor. Despite these observed $\mathrm{pH}$ range being relevant for some natural water samples, several industrial effluents are strongly alkalines, with $\mathrm{pH}$ between 10 and $12 .{ }^{16} \mathrm{~A}$ dialysis sampler can be used for collection of phenolic compounds and their internal deliver to be amperometricaly detected by the biosensor avoiding this drawback, since the internal solution will give optimal conditions. ${ }^{9,20}$ Figure 3 (B) shows the influence of the sample $\mathrm{pH}$ upon the laccase- (a) and tyrosinase-based (b) biosensors response when the dialysis system was employed. Such profiles were obtained using a $10 \mathrm{mmol} \mathrm{L}^{-1}$ phosphate buffer solution at $\mathrm{pH} 5.0$ (for laccase-based biosensor) or $\mathrm{pH} 5.5$ (for tyrosinase-based

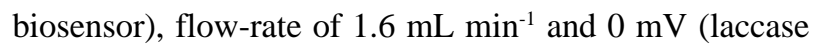
biosensor) or $50 \mathrm{mV}$ (tyrosinase biosensor) vs $\mathrm{Ag} / \mathrm{AgCl}$. It can be observed that, using this dialysis system, the responses of the biosensors are almost independent on the sample $\mathrm{pH}$, over the range between 2 and 14, improving the monitoring applications.
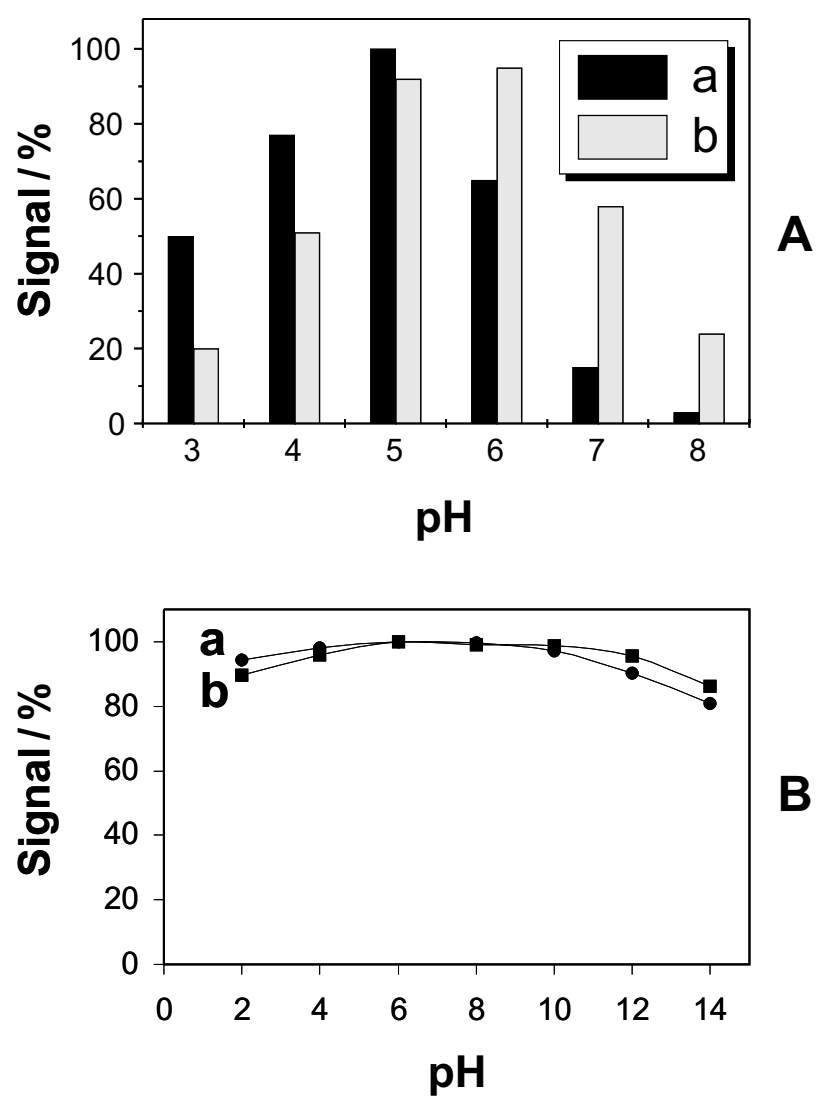

Figure 3. Variation of the current intensity with $\mathrm{pH}$ for the system without (A) and with membrane (B); laccase-based (a) and tyrosinase-based (b) biosensors. Potential step to $0.0 \mathrm{~V}$ and 0.05 vs $\mathrm{Ag}$ / $\mathrm{AgCl}$; for laccase- and tyrosinase-based biosensors, respectively. Other conditions, as in Figure 2. 


\section{Stability}

The laccase (a) and tyrosinase-based (b) biosensors showed a good long-term stability, as verfied by data from repetitive analysis recorded at 10 minutes intervals over a prolonged period (presented in Figure 4). The laccasebased biosensor showed a relative standard deviation of $2.8 \%$ for a series of 24 successive measurements of $50 \mu \mathrm{mol} \mathrm{L}^{-1}$ guaiacol. A similar stability, $\mathrm{RSD}=3.9 \%$, was observed for the tyrosinase-based biosensor using $50 \mu \mathrm{mol} \mathrm{L}{ }^{-1}$ phenol. In addition, the bioactivity was maintained over a long period, $90 \%$ for laccase- and $73 \%$ for tyrosinase-based biosensor after 300 determinations.

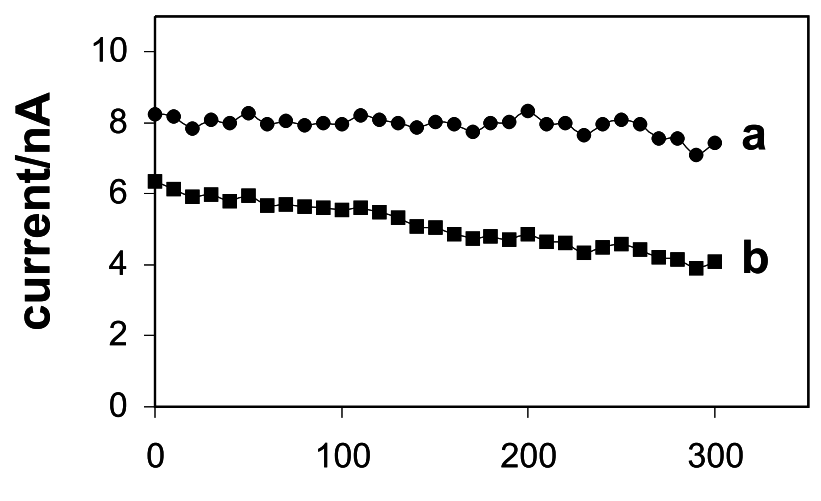

number of determinations

Figure 4. Stability experiments for laccase-based (a) and tyrosinase-based (b) biosensors. Injected volume: $220 \mu \mathrm{L}$ of $50 \mu \mathrm{mol} \mathrm{L}^{-1}$ guaiacol (for laccase biosensor) and $220 \mu \mathrm{L}$ of $50 \mu \mathrm{mol} \mathrm{L}^{-1}$ phenol (for tyrosinase biosensor). Potential step to $0.0 \mathrm{~V}$ and $0.05 \mathrm{vs} \mathrm{Ag} /$ $\mathrm{AgCl}$; for laccase- and tyrosinase-based biosensors, respectively. Flow injection conditions, as in Figure 2.

\section{Analytical curves for phenolic compounds}

The laccase and tyrosinase biosensors offer different selectivity for different phenolic compounds. Table 1 shows the sensitivity of these two enzymatic biosensors for different phenolic compounds: phenol, p-chlorophenol, guaiacol and p-chloroguaiacol. The laccase-based sensor displays high sensitivity to p-chloroguaiacol and guaiacol.
However, this biosensor showed a low response for phenol and p-chlorophenol. On the other hand, the tyrosinasebased biosensor was effective in detecting p-chlorophenol and phenol, but ineffective for p-cloroguaiacol and guaiacol.

Strictly linear calibration curves were obtained from $1.0 \mu \mathrm{mol} \mathrm{L}^{-1}$ to $10.0 \mu \mathrm{mol} \mathrm{L} \mathrm{L}^{-1}$ for guaiacol and chloroguaiacol, using the laccase-based biosensor; as well as for phenol and chlorophenol, using the tyrosinase-based biosensor. These analytical curves were adjusted by the equations: $\mathrm{i}(\mathrm{nA})=0.122 \pm 0.003\left(\mathrm{nA} / \mu \mathrm{mol} \mathrm{L}^{-1}\right)$ [guaiacol], $\mathrm{r}^{2}=0.999 ; \mathrm{i}(\mathrm{nA})=0.061 \pm 0.002\left(\mathrm{nA} / \mu \mathrm{mol} \mathrm{L}^{-1}\right)$ [chloroguaiacol], $\mathrm{r}^{2}=0.999 ; \mathrm{i}(\mathrm{nA})=0.091 \pm 0.003(\mathrm{nA} /$ $\left.\mu \mathrm{mol} \mathrm{L}^{-1}\right)$ [phenol], $\mathrm{r}^{2}=0.999$ and $\mathrm{i}(\mathrm{nA})=0.131 \pm 0.005$ $\left(\mathrm{nA} / \mu \mathrm{mol} \mathrm{L}^{-1}\right)$ [chlorophenol], $\mathrm{r}^{2}=0.999$.

Detection limits around $1.1 \times 10^{-7} \mathrm{~mol} \mathrm{~L}^{-1}$ for guaiacol and $1.9 \times 10^{-7} \mathrm{~mol} \mathrm{~L}^{-1}$ for chloroguaiacol could be estimated for the laccase-based biosensor considering $3 \sigma_{\mathrm{B}}$. Using the tyrosinase-based biosensor detection limits of $1.5 \times 10^{-7}$ mol L $\mathrm{L}^{-1}$ for phenol and $9.0 \times 10^{-8} \mathrm{~mol} \mathrm{~L}^{-1}$ for chlorophenol were obtained. The responses of both biosensors were linear in the concentration range up to $100 \mu \mathrm{mol} \mathrm{L}^{-1}$.

\section{Analysis of paper mill effluent}

The selectivity and sensitivity of the biosensors allow a convenient quantification of phenolic compounds in relevant environmental samples. Figure 5 displays the response of the tyrosinase-based biosensor to phosphate buffer (A) and untreated Kraft E1 paper mill effluent (B) samples containing increasing levels of phenol. A favorable response is observed in both media up to $10 \mu \mathrm{mol} \mathrm{L}^{-1}$ concentration changes (a-e). These results show that this biosensor can be used successfully to performe a selective analysis of phenols in complex environmental samples with high sensitivity and low interference.

A similar behavior was also observed for the laccasebased biosensor upon the response for guaiacol/ chloroguaiacol in the same kind of sample (data not shown).

Table 2 shows the phenolic content in a Kraft E1 paper mill effluent sample, detected using the laccase, tyrosinase-

Table 1. Laccase- and tyrosinase-based biosensor sensitivity for different phenolic compounds, obtained from the analytical curves with $\mathrm{n}=10$. Flow injection conditions and potential, as in Figure 2

\begin{tabular}{lcccc}
\hline & \multicolumn{2}{c}{ LACCASE } & \multicolumn{2}{c}{ TYROSINASE } \\
\cline { 2 - 5 } Compound & Sensitivity $\left(\mathrm{nA} / \mu \mathrm{mol} \mathrm{L}{ }^{-1}\right)$ & Correlation coefficient $\left(\mathrm{r}^{2}\right)$ & Sensitivity $\left(\mathrm{nA} / \mu \mathrm{mol} \mathrm{L}{ }^{-1}\right)$ & ${\text { Correlation coefficient }\left(\mathrm{r}^{2}\right)}$ \\
\hline phenol & $0.008 \pm 0.001$ & 0.998 & $0.091 \pm 0.003$ & 0.999 \\
p-chlorophenol & $0.009 \pm 0.001$ & 0.998 & $0.131 \pm 0.005$ & 0.999 \\
guaiacol & $0.122 \pm 0.003$ & 0.999 & $0.006 \pm 0.001$ & 0.989 \\
p-chloroguaiacol & $0.061 \pm 0.002$ & 0.999 & $0.005 \pm 0.001$ & 0.988 \\
\hline
\end{tabular}




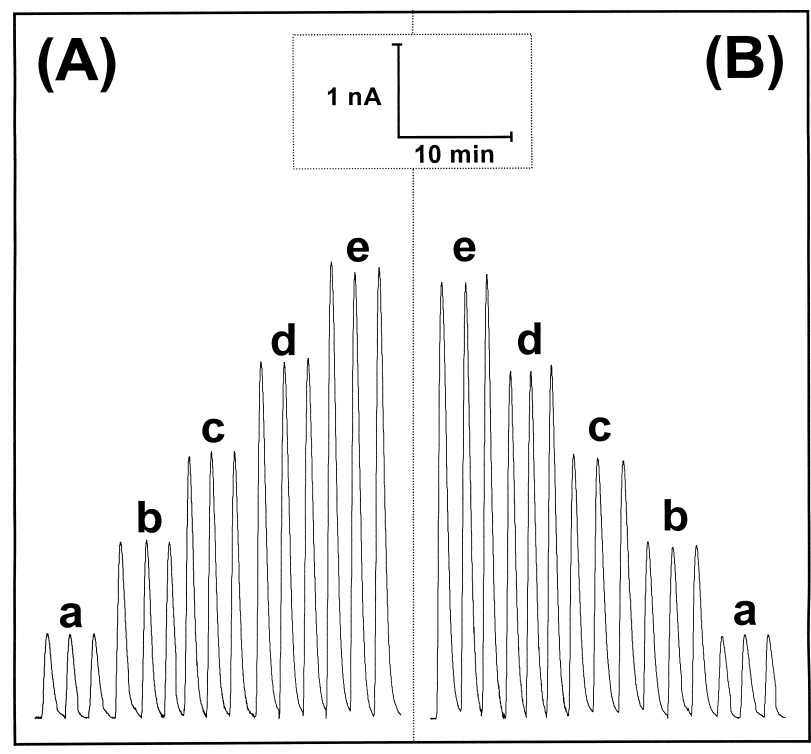

Figure 5. Tyrosinase-based biosensor response to phosphate buffer at $\mathrm{pH} 5.5$ (A) and untreated Kraft E1 paper mill effluent under natural $\mathrm{pH}$ and ionic strength (B) samples containing increasing levels of phenol $10 \mu \mathrm{mol} \mathrm{L}^{-1}$ (from a to e). Potential step to $0.0 \mathrm{~V}$ and 0.05 vs Ag/AgCl; for laccase- and tyrosinase-based biosensors, respectively. Flow injection conditions, as in Figure 2.

Table 2. Results obtained by the standard addition method for the phenolic content determination in Kraft E1 paper mill effluent, employing different biosensors (laccase and tyrosinase), as well as the colorimetric method

\begin{tabular}{cc}
\hline Method & Phenolic content $\left(\mathrm{mg} \mathrm{L}^{-1}\right)$ \\
\hline Laccase biosensor & $0.19 \pm 0.01$ \\
Tyrosinase biosensor & $2.74 \pm 0.10$ \\
Colorimetric method & $25.27 \pm 1.48$ \\
\hline
\end{tabular}

based biosensors and the Folin-Ciocalteu colorimetric method. The phenolic concentrations found are completely different from each other. The difference between the colorimetric method and the biosensors can be explained due to the low selectivity presented by the colorimetric method. This method shows a positive response to a broad range of compounds, such as phenols, tannins and lignins. In addition, lignin fragments are abundant in this kind of effluent since lignin is one of the components of wood, which is the raw material of pulp and paper. On the other hand, the biocatalytic recognition of the biosensors offers highly selective measurements of the studied phenolic compounds. Thus, these biosensors do not allow the total phenol quantification as a consequence of their inherent selectivity. Another analytical method should be used to estimate the total phenolic content in the paper mill effluent. However, this is not a simple task, since this kind of effluent presents more than 300 different organic compounds, ${ }^{16}$ a high $\mathrm{pH}$ value, suspense solids and others extreme conditions, which difficult the continuous analysis of the target compounds. Therefore, using biosensors designed to monitor compounds that are really important in the environmental aspects, may provide more accurate information about the effluent.

The difference between the biosensors concentrations, once again is because these biosensors have distinct sensitivity for different phenolic compounds, as showed in Table 1. A careful analysis of data in Table 2 suggests that both biosensors responded basically to phenol, and this is an indication that guaiacols concentration, in the studied effluent, is very low. Although these biosensors showed different selectivity for different phenolic compounds, they cannot distinguish between each individual analyte. Thus, the combination of these two or more biosensors can improve the accuracy and reliability of phenols determination. Moreover, coupling different selective biosensors is an alternative to promote an efficient screening of a broad range of phenolic compounds, which will give a more useful chemical information than the total phenol content in the effluent.

\section{Conclusion}

The experiments described in this work illustrate the ability to employ a flow system with a dialysis sampler and a bio-electrochemical detector for continuous monitoring phenolic compounds in environmental samples. The laccase and tyrosinase-based biosensor showed good sensitivity and stability. In addition, the selectivity of these enzymes allowed the detection and quantification of some phenolic compounds in samples of environmental interest. Continuous measurement of phenolic compounds in the affected natural environment can provide an appropriate feedback during the characterization or remediation of contaminated sites. Thus, the proposed flow system can increase the quality of monitoring activities.

Finally, the proposed device can be readily adapted for accommodating similar enzyme-based probes (e.g. peroxidase-based) for other phenolic compounds, which will allow a selective monitoring of several compounds in complex environmental matrices.

\section{Acknowledgments}

Financial support from FAPESP, PRONEX. 


\section{References}

1. Ortega, F.; Domínguez, E.; Burestedt, E.; Emneus, J.; Gorton, L.; Marko-Varga, G.; J. Chromatogr., A 1994, 675, 65.

2. Rogers, K.M.; Becker, J.Y.; Cembrana, J.; Chough, S.H.; Talanta 2001, 54, 1059.

3. Russell, I.M.; Burton, S.G.; Anal. Chim. Acta 1999, 389, 161.

4. Rossato, S.S.; Freire, R.S.; Durán, N.; Kubota, L.T.; Quim. Nova 2001, 24, 77.

5. Canofeni, S.; DiSario, S.; Mela, J.; Pilloton, R.; Anal. Lett. 1994, 27, 1659.

6. Nistor, C.; Emneus, J.; Gorton L.; Ciucu, A.; Anal. Chim. Acta 1999, 387, 309.

7. Gundersen, J.L.; Macintyre, W.G.; Hall, R.C.; Environ. Sci. Technol. 1997, 31, 188.

8. Wang, J.; Trends Anal. Chem. 1997, 16, 84.

9. Wang, J.; Lu, J.; Ly, S.Y.; Tian, B.; Adeniyi, W.K.; Armendariz, R.A.; Anal. Chem. 2000, 72, 2659.

10. Wang, J.; Chen, Q.; Anal. Chim. Acta 1995, 312, 39.

11. Cosnier, S.; Fombon, J.J.; Labbe, P.; Limosin, D.; Sens. Actuators, B 1999, 59, 134.

12. Yaropolov, A.I.; Kharybin, A.N.; Emnéus, J.; Marko-Varga, G.; Gorton, L.; Anal. Chim. Acta 1995, 308, 137.
13. Freire, R.S.; Durán, N.; Kubota, L.T.; Talanta 2001, 54, 681.

14. Freire, R.S.; Thongngamdee, S; Durán, N.; Wang, J.; Kubota, L.T.; Analyst 2001, 127, 258.

15. APHA, Standard Methods for Examination of Water and Wastewater, $17^{\text {th }}$ ed., Amer. Publ. Health Ass. $\mathrm{N}^{0}$ 5550: New York 1989.

16. Freire, R.S.; Kubota, L.T.; Durán, N.; Environ. Technol. 2001, $22,897$.

17. Burestedt, E.; Narvaez, A.; Ruzgas, T.; Gorton, L.; Emneus, J.; Dominguez, E.; Marko-Varga, G.; Anal. Chem. 1996, 68, 1605.

18. Rogers, K.R.; Becker, J.Y.; Cembrano, J.; Electrochim. Acta 2000, 45, 4373.

19. Marko-Varga, G.; Emneus, J.; Gorton, L.; Ruzgas, T.; Trends Anal. Chem. 1995, 14, 319.

20. Freire, R.S.; Duran, N.; Kubota, L.T.; Anal. Chim. Acta 2002, in press.

Received: December 19, 2001

Published on the web: June 12, 2002

FAPESP helped in meeting the publication costs of this article. 